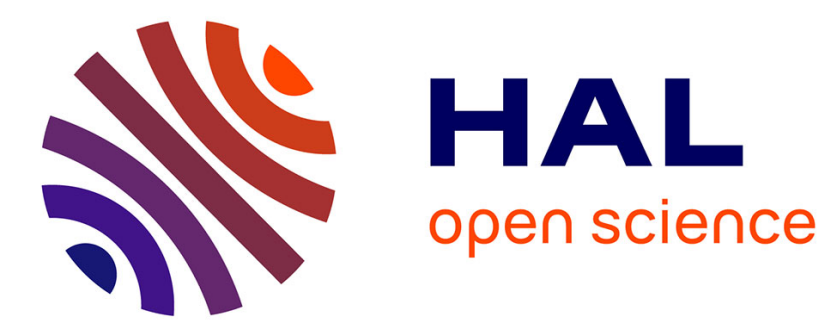

\title{
Biogeochemical ocean-atmosphere transfers
}

Ronald Prinn, Peter Liss, Patrick Baut-Menard

\section{To cite this version:}

Ronald Prinn, Peter Liss, Patrick Baut-Menard. Biogeochemical ocean-atmosphere transfers. Global Biogeochemical Cycles, 1993, 7 (2), pp.245-246. 10.1029/93GB00870 . hal-03585081

\section{HAL Id: hal-03585081 https://hal.science/hal-03585081}

Submitted on 22 Feb 2022

HAL is a multi-disciplinary open access archive for the deposit and dissemination of scientific research documents, whether they are published or not. The documents may come from teaching and research institutions in France or abroad, or from public or private research centers.
L'archive ouverte pluridisciplinaire HAL, est destinée au dépôt et à la diffusion de documents scientifiques de niveau recherche, publiés ou non, émanant des établissements d'enseignement et de recherche français ou étrangers, des laboratoires publics ou privés. 


\section{BIOGEOCHEMICAL OCEAN-ATMOSPHERE TRANSFERS}

\author{
Ronald Prinn \\ Massachusetts Institute of Technology, Cambridge
}

Peter Liss

University of East Anglia, School of Environmental

Science, Norwich, United Kingdom

Patrick Baut-Menard

Centre des Faibles Radioactivities, Domaine du

Centre National de la Recherche Scientifique

Gif-sur-Yvette, France
The exchange of trace gases and aerosols between the atmosphere and the ocean is an important process in the biogeochemical cycling of both biologically important elements and radiatively important compounds. This exchange process thus plays a significant role in both sustaining life in the ocean and determining the global radiative balance. These exchanges are complex involving biological and chemical processes in the sea, chemical and radiative processes in the air, and transport processes in both the atmosphere and the ocean. To give three specific examples: biological production followed by emissions of dimethyl sulfide (DMS) from the ocean leads to production of acidic cloud condensation nuclei with important implications for global marine cloud cover and thus albedo; atmospheric transport followed by deposition of ironcontaining atmospheric aerosols into the ocean leads to fertilization with possible important effects on net carbon dioxide removal through the biological planktonic pump; and, transfer of carbon compounds between atmosphere and ocean is a critical process in determining global atmospheric levels of carbon dioxide and marine atmospheric levels of reactive hydrocarbons.

Yet despite the acknowledged importance of oceanatmosphere exchange, there are some remarkable gaps in our current knowledge of mechanisms and rates. Some of the important gaps could be removed if the requisite atmospheric and oceanographic research communities pooled their resources and expertise. This cooperation has not yet happened on a broad scale. There is therefore a clear need in the

Copyright 1993

by the American Geophysical Union

Paper number 93GB00870

0886-6236/93/93GB-00870\$02.00 future for cooperative study and experiments by atmospheric and oceanic scientists in this area.

The importance of ocean-atmosphere exchange processes and the existence of many unanswered questions regarding these processes led to the NATO Advanced Research Workshop, "Biogeochemical Ocean-Atmosphere Transfers" (BOAT), which was held at the Bermuda Biological Station from January 27 to 31,1992 . It was attended by 39 scientists representing two communities: atmospheric chemistry and physics, and oceanic biogeochemistry. The goals of the workshop were (1) to define the major unresolved problems involved in exchanges of trace gases and aerosols between the atmosphere and the oceans which are important to global climate change, and (2) to plan future collaborative oceanic experiments to address these problems within the context of global change studies conducted jointly by two International Geosphere-Biosphere Program (IGBP) Core Projects: the Joint Global Ocean Flux Study (JGOFS) [1992] and the International Global Atmospheric Chemistry [IGAC) [1992] Project.

The first half of the BOAT Workshop was devoted to a critical examination of current measurements, models, and understanding of the important transfers and cycling processes. Three subjects were of specific interest: (1) ocean outputs (DMS, nitrous oxide, nonmethane hydrocarbons, halogenated hydrocarbons, etc.) and atmospheric chemical roles; (2) atmospheric inputs (nitrogen, iron, etc.) and oceanic biogeochemical roles; (3) carbon dioxide cycling. Original papers on these three subjects based in part on presentations at the Workshop appear in this journal [see Fasham et al., this issue; Moore and Tokarczyk, 1993; Plass-Dülmer et al., 1993; Ratte et al., 1993; Sarmiento et al., this issue; Yoder et al., 1993; also P. Holligan et al., A biogeochemical study of the coccolithophore, Emiliani huxleyi, in the North Atlantic, submitted to Global Biogeochemical Cycles, 1993; T. J. Takahashi et al., Seasonal variation of $\mathrm{CO}_{2}$ and nutrient salts over the high-latitude 
oceans: A comparative study, submitted to Global Biogeochemical Cycles, 1993]. This examination led into the second half of the Workshop, which identified six major areas of current ignorance and formulated plans for future research in these areas.

The six areas where cooperative experiments involving atmospheric and oceanic scientists could yield significant dividends are: (1) impact of atmospheric deposition on new production. Specifically inputs of $\mathrm{NO}_{3}^{-}$and $\mathrm{Fe}^{++}$from the atmosphere to the ocean may be significant if not limiting to productivity in some areas but the process and its effects need to be better understood and quantified, (2) production and cycling of trace gases in the ocean. While several trace gases produced in seawater and emitted to the atmosphere play significant roles in its chemistry and physics, there is a lack of understanding of the mechanisms controlling the spatial and temporal distribution of these gases in the oceans, (3) processes controlling gas exchange rates. There is a clear need to improve our understanding of the processes controlling air-sea gas exchange rates and to reduce the current factor of 2 uncertainty in calculated transfer velocities, (4) marine boundary layer chemistry. Current knowledge of the mix of chemicals and the resultant chemistry in the remote marine boundary layer is insufficient to constrain local oxidation rates to much better than a factor of 2 . Rates of condensation nucleii formation are even more poorly constrained, (5) global measurements. To answer outstanding questions relevant to global budgets, to provide data for model validation, and to determine boundary fluxes for atmospheric chemistry.studies, new global oceanic measurements are required for $\mathrm{CO}_{2}$ and other gases $\left(\mathrm{N}_{2} \mathrm{O},\left(\mathrm{CH}_{3}\right)_{2} \mathrm{~S}\right)$, and (6) modeling biogeochemical fluxes between ocean and atmosphere. With the development of three-dimensional atmospheric and oceanic general circulation models, large-scale biogeochemical modeling of air-sea transfer is now possible and could help considerably in defining the global cycles of $\mathrm{CO}_{2},\left(\mathrm{CH}_{3}\right)_{2} \mathrm{~S}$, OCS, and $\mathrm{N}_{2} \mathrm{O}$.

To address these six problem areas, a number of concrete undertakings have been proposed by the BOAT participants utilizing joint oceanographic cruises and joint modeling activities and these will be described in detail elsewhere. The purpose of this commentary is first to seek additional input on the above six problems and second to alert the relevant atmospheric and oceanic research communities to the need for co- operation in solving these problems. The potential exists through this cooperation for improving very significantly the scientific accomplishments of both the JGOFS and the IGAC Project.

\section{REFERENCES}

Fasham, M. J. R., J. L. Sarmiento, R. D. Slater, H. W. Ducklow, and R. Williams, Ecosystem behavior at Bermuda Station "S" and Ocean Weather Station "India": A general circulation model and observational analysis, Global Biogeochemical Cycles, this issue.

International Global Atmospheric Chemistry Project,Overview and activities, Core Proj. Off., Cambridge, Mass., 1992.

Joint Global Ocean Flux Study, Implementation plan, Rep. 23, Box 50005, S-10405, Int. Global Atmos. Chem., Stockholm, Sweden, 1992.

Moore, R. M, and R. Tokarczyk, Volatile biogenic halocarbons in the Northwest Atlantic, Global Biogeochemical Cycles, 7, 195-210, 1993.

Plass-Dülmer, C., A. Khedim, R. Koppmann, F. J. Johnen, J. Rudolph, and H. Kuosa, Emissions of light nonmethane hydrocarbons from the Atlantic into the atmosphere, Global Biogeochemical Cycles, 7, 211-228, 1993.

Ratte, M., C. Plass-Dülmer, R. Koppmann, and J. Rudolph, Production mechanism of $\mathrm{C} 2-\mathrm{C} 4$ hydrocarbons in seawater: Field measurements and experiment, Global Biogeochemical Cycles, 7, 195-210, 1993.

Sarmiento, J. L., R. D. Slater, M. J. R Fasham, H. W. Ducklow, J. R. Toggweiler, and G. T. Evans, A seasonal three-dimensional ecosystem model of nitrogen cycling in the North Atlantic euphotic zone, Global Biogeochemical Cycles, this issue.

Yoder, J. A., C. R. McClain, G. C. Feldman, and W. E. Esaias, Annual cycles of phytoplankton chlorophyll concentrations in the global ocean: A satellite view, Global Biogeochemical Cycles, 7, 181-194, 1993.

(Received March 17, 1993; revised March 28, 1993; accepted March 30, 1993.) 